\title{
Jesuit Exegesis, Jacobean Theology, and the Scottish Church in the First Two Decades of the Seventeenth Century
}

\author{
Mark W. Elliott \\ University of Glasgow \\ Mark.Elliott@glasgow.ac.uk
}

\begin{abstract}
This paper aims to sketch a little of the background history of the ideas behind the events that led to the martyrdom of John Ogilvie. In so doing, no pretense is made at reducing politics, religion, personal commitment and loyalty to one single ideological cause, nor, even worse, claim that ideologies drove people and events before them like skittles. The aim is more modest than that of tracing a series of causes and effects. If it fails to enmesh with the historical realities such as traced by eminent historians such as Durkan and Dilworth, ${ }^{1}$ nevertheless it might still help in the interpretation of these lives and events.
\end{abstract}

\section{Keywords}

Society of Jesus - James vi and I - John Ogilvie - Robert Bellarmine - Juan Maldonado biblical exegesis - theology - divine right of kings

1 Mark Dilworth, "Three Documents Relating to St John Ogilvie," Innes Review 34, no. 2 (1983): 51-65; St John Ogilvie S.J., 1579-1615: An Illustrated History of His Life, Martyrdom and Canonization, ed. Christopher Carrell and Gail Boardman (Glasgow: Third Eye Centre, 1979); John Durkan, “Miscellany: 'John Ogilvie's Glasgow Associates," Innes Review 21, no. 2 (1970): 153-56; John Durkan, “Two Jesuits: Patrick Anderson and John Ogilvie," Innes Review 21, no. 2 (1970): $157-61$.

(C) MARK W. ELLIOTT, 2020 | DOI:10.1163/22141332-00701005

This is an open access article distributed under the terms of the prevailing CC-BY-NC-ND 4.0 license. 
Working backwards through the title, "the first two decades" is somewhat loosely to be understood as including the 159os, but not going beyond 1615 . The complicated, winding history of the Scottish church of that period could take a book or more to explain. At risk of over-simplification, it would be fair to say that some amount of a "parting of the ways" between those of the New and the Old Faith had taken place by the early 1580 os at the latest, as attested by the king's or the Negative Confession of 1581. This was a document that spoke of doing God's will by not doing as others do, hence, not being idolatrous, as Israel was to copy the Canaanites, or, according to this typological self-understanding, of being the true Reformed Kirk before international Catholicism. The narrative of "them and us" (and "us" as "not them" in their practices and underlying beliefs) was well recited a generation before 1615. However, as has been noted, the majority or coming of age of James VI (1566-1625; r. [Scotland] 1567-1625 [England] 1603-25) in the 1590s would, at least seen from a certain angle, inaugurate something of a backlash that had echoes of the policy of his minority under the regency of James Stewart, earl of Arran (c.1545-96) (the Black Acts of 1584 with their suppression of Presbyterianism and the re-establishment of episcopacy are documented, which could be interpreted as an encouragement to Catholics). ${ }^{2}$ There had been at least two attempts to convert James back to the faith of his mother; once in 1582 during discussions about a tutor to replace George Buchanan (1506-82), and again in the years just prior to the middle-aged James's succession to the English throne; these seem to have been either half-hearted in attempt or just too difficult in execution. It might actually be the case that the 1598 recall and restoration (with revenues, although he stayed and died in Paris, in 1603) of the old Catholic archbishop James Beaton (1524-1603) from France was less a sign of his "crypto-papism" and more an expression that the king was above taking sides in national religious dispute. ${ }^{3}$

2 That Andrew Melville and his "Genevan" polity did not have things all their own way: see Alan MacDonald, The Jacobean Kirk: Sovereignty, Polity and Liturgy, 1567-1625 (Farnham: Ashgate, 1998); Alan MacDonald, "Best of Enemies: Andrew Melville and Patrick Adamson, c.1574-1592," in Sixteenth-Century Scotland: Essays in Honour of Michael Lynch, ed. Julian Goodare and Alasdair MacDonald (Leiden: Brill, 2008), 257-76. Also, David George Mullan, Scottish Puritanism, 1590-1638 (Oxford: Oxford University Press, 2000); Ian Hazlett, "Cold War Theology: A Controversial Religious Image of King James VI \& I in England and on the Continent in 1603," Theology in Scotland 19 (2012): 35-62.

3 See Mark Dilworth, "Archbishop James Beaton II: A career in Scotland and France," Records of the Scottish Church History Society 23 (1987-89): 301-16. 
This wish to stand above, oversee and control matters religious in his realm was expressed both in James's summoning and attendance of every General Assembly from 1597 to 1603 and in his book Basilikon doron of 1599, that articulation of the divine right of kings, addressed to his ill-fated son Henry. Some of the practical implications included: the king is to judge when preachers err; the king is to summon church assemblies; that to insist on parity among ministers is confusing; that moderate men make better ministers. Next, what was Episcopalian sauce for the English goose at Hampton Court in 1604 became sauce for the Scottish gander from 1610 onwards with the active encouragement of the monarch. In these struggles between Presbyterians and Episcopalians, one might be forgiven for wondering where the remaining Catholics were. As is well known, at least in those early few decades where the Protestant religion was not so established, and it was not unthinkable that Scotland might just find its way back to Rome, ${ }^{4}$ Catholics continued to worship in areas, such as the north-east where they were protected by co-religionists in high places, with even the monarch at times sending mixed signals. The issue of young men with vocations required to keep the church alive was perhaps not as difficult as it sounds, even if the return had to be secretive and this almost impossible given the extent and competence of governmental spy networks. For many Protestants who left for overseas to receive most of their training fitted in quite well once back home, ${ }^{5}$ although in the long-term there was no substitute for having some form of local seminary or college where bonds of mutual loyalty as well as standardized training could be fashioned.

However, this is not the place to try to define just what "the Church" in Scotland was in those years. It does need to be registered quite early on that Catholics truly numbered among royalists, when many of the more Presbyterianminded, such as John Knox (c.1514-72), George Buchanan, and Andrew Melville (1545-1622), allied their church polity to a political republicanism. One thinks of royalists such as Ninian Winzet (1518-92) and Adam Blackwood (1539-1613).

4 On hopes for James's conversion in the early 1580s, see Thomas M. McCoog, The Society of Jesus in Ireland, Scotland and England 1541-1588: “Our Way of Proceeding?”(Leiden: Brill, 1996), 178-223.

5 Two older books provide insight into this phenomenon: Andrew L. Drummond, The Kirk and the Continent (Edinburgh: St Andrews Press, 1956); George D. Henderson, The Burning Bush (Edinburgh: St Andrews Press, 1957). 
Then there was William Barclay (1546-1608), writing in exile in France, like many hoping for the religious wind to change, yet whose ambitions for the godly prince in practice and his high monarchical arguments brought him into conflict with Jesuit political theorists of the first decade of the century. ${ }^{6}$ As James H. Burns puts it:

Both in De regno (160o) and in De potestate Papae (1609) Barclay can agree (with Bellarmine, for instance) that succession to the crown is a matter for human law and that popular consent may in some sense be a necessary preliminary to a king's accession. The fact remains that a king once enthroned is entitled to his subjects' submission and obedience with all due honour and reverence; and all this by nothing less than divine precept. ${ }^{7}$

This would have sounded like sweet music to the ears of his Majesty, which very much stood on its dignity in terms of regal authority in the land, but whose intention was to go much further and stray into territory marked "Religion-keep out," just as Andrew Melville had discovered in 1596 at Falkland Palace, when he tried to exercise spiritual authority over James. Two sound-bites from the Basilikon doron, as he addresses his princely son are particularly indicative:

your office is likewise mixed, betwixt the Ecclesiasticall and civill estate: For a King is not mere laicus and both the Papists and Anabaptists would have him, to which error also the Puritans incline over farre (III, 45).

Kings are called Gods by the propheticall King David (Ps 82.1), because they sit upon God his throne in the earth, and have the count of their administration to give unto him. (III, 54).

Archbishop John Spottiswood (1565-1639), James's man in the north, was the nemesis of dissenting ministers such as Melville and Robert Bruce, so that by the time he came face to face with John Ogilvie (1579-1615) after the latter's arrest he was well used to threats made by capable people to the face of divine

6 Cf. Marie-Claude Tucker, “Barclay, William (1546-1608)," оDNB http://www.oxforddnb.com/ view/article/1352 (accessed September 18 , 2019).

7 James H. Burns, "George Buchanan and the Anti-monarchomachs," in Political Discourse in Early Modern Britain, ed. James H. Burns (Cambridge: Cambridge University Press, 1993), 3-22. See also Lori Anne Ferrell, Government by Polemic:James I, the King's Preachers and the Rhetorics of Conformity, 1603-1625 (Stanford: Stanford University Press, 1998). 
right monarchy with its implications for the realm of faith. It was of course really a case of mutual trespass. For on the Catholic side the famous words of Robert Bellarmine (1542-1621) seem just as clear:

Habet Summus Pontifex jure divino potestatem disponendi de rebus temporalibus Christianorum in ordine ad finem spiritualem (By divine right the Supreme Pontiff has the power to dispose in temporal matters of Christians in ordaining things for spiritual purpose). ${ }^{8}$

Historian Harro Höpfl concludes that for all the brilliance of Francisco Suárez (1548-1617) and Bellarmine, they could not hope to keep Catholic monarchs on board, let alone non-Catholic ones, by insisting that the pope had the right not only to give counsel to rulers, but also to force it upon them. ${ }^{9}$ Yet that is what the theory of potestas indirecta amounted to: it meant pressure on princes and peoples to work in and through temporal matters for the sake of a papally defined spiritual end. The Jesuit political theory had arguably got itself into a cul-de-sac, one which otherwise faithful Catholics like Barclay could exploit in works that John Locke (1632-1704) would engage with more than eighty years later. Rome itself was split: the emperor's canon lawyer Francisco Peña (c.1540-1612) in 1611 produced his De regno Christi, which argued that the pope's authority over monarchs was purely and "merely" spiritual, i.e. that did not involve temporal matters. According to Höpfl, the 1610 Jesuit ban on even discussing tyrannicide (confirmed by the general of the order, Claudio Acquaviva [1543-1615; in office $1581-1615]$ in 1614) as evidence that the logical corollary of their theory of indirect power-i.e. that no oath of allegiance to a king could trump the conviction that the pope had de iure power to excommunicate the monarch for heresy and depose him - had done the order and the papacy harm. The promulgation of this ban does seem like backtracking from a counterproductive position. The Martin Becanus (1563-1624) case, well documented by historian Stefania Tutino, makes this clear. ${ }^{10}$ As Tutino concludes: "This does not mean the doctrine of the potestas indirecta led directly to James's absolutism [...] but [...]."11

8 Robert Bellarmine, Tractatus de potestate Summi Pontificis in rebus temporalibus aduersus Gulielmum Barclaium (Rome, 1610), 66.

9 Harro Höpfl, Jesuit Political Thought: The Society of Jesus and the State, c.1540-1630 (Cambridge: Cambridge University Press, 2004).

10 Stefania Tutino, Empire of Souls: Robert Bellarmine and the Christian Commonwealth (Oxford: Oxford University Press, 2011).

11 Tutino, Empire of Souls, 210. 
As Höpfl notes: “The Society's spokesmen, however, felt compelled to continue to assert the papal "indirect" authority in temporalibus. Denying this authority was to deny the character of the church as the respublica christiana."12 Indeed, Bellarmine was adamant: "For the unity of faith to be preserved, advice is not enough; what is needed is power (imperium)."13 That often seemed a climb down from a medieval position of asserting full temporal power of the pope as princeps mundi (the leader of the world). Bellarmine had written, although he did not publish, the 1605 Hieratikon doron, a response to James's above-mentioned famous work. He contended that George Blackwell, archpriest of England, had sworn the oath of allegiance but should not have done so. In fact, the pope reserves the right to excommunicate and if a Catholic swears the oath, they should immediately reverse this. ${ }^{14}$

Where James pushed things too far, in Bellarmine's view, was in his demand for a certain type of allegiance: James in demanding an oath of allegiance demanded that Catholics took issue with a teaching of the church (that it could excommunicate whomsoever it liked), and this was to veer on to theological and religious territory. There was only one thing in the oath they baulked at, but that one thing meant they could not swear it at all. Most if not all Catholics were loyal subjects. They mostly abhorred the Gunpowder Plot of 1605. Analogously, although Jesuits were implicated in the assassinations of the two Henris in France, there had been no actual threat of excommunication made to James. "But for Protestants, it was not merely an empirical matter that the Pope would act arbitrarily (pro arbitrio), but virtually a necessary truth. Since he was Anti-Christ, his actions were necessarily dictated by corrupt motives and pro arbitrio."15 James VI and I himself did not feel under threat, but he could turn the situation to his advantage: he showed himself to be anti-Roman (pleasing the Reformed) and also to assert his claim to governance of the church in his nation. Henri IV (r.1594-1610) had been too conciliatory with the Jesuits, employing what historian Eric Nelson calls "royal douceur" in patronizing them (for example with twenty-three new Jesuit colleges), while demanding an oath (in the Edict of Rouen [1603]), ${ }^{16}$ and had arguably shown weakness by allowing them to proselytize Huguenots. Henri's assassination was more a Spanish "political" move and one which threatened the Jesuit order, whose theoretical

\footnotetext{
12 Höpfl, Political Thought, 346.

13 Bellarmine, Bk 1; Höpfl, Political Thought, 355.

14 Tutino, Empire, 139.

15 Tutino, Empire, 327.

16 Eric Nelson, The Jesuits and the Monarchy: Catholic Reform and Political Authority in France (1590-1615) (Aldershot: Ashgate, 2005), 99-101.
} 
writings had switched from discussing regicide to discussing martyrdom. ${ }^{17} \mathrm{Al}-$ though he would not shift from the Thirty-Nine Articles without which the Elizabethan settlement and his own monarchy could not have existed, James would not clamp down on Catholics, so long as they were loyal subjects, to the annoyance of Willet and Andrewes. ${ }^{18}$ On the other side, while papal supremacy in national politics was really on the decline, "Bellarmine wanted to carry the fight against the king by winning over the souls rather than bodies."19 It became about conscience and passivity: yet ironically that could raise the stakes.

So, in practice recusancy was rarely a problem and most knew that. But as soon as the king's principle was challenged by the case of a priest who had been arrested for saying mass in a populated and highly Reformed part of Scotland and refusing to desist, the exceptional could quickly come to form the rule. Furthermore, if the size of its seminary was anything to go by, Glasgow was the most Reformed of all: there was not a sniff of softening on Calvinist doctrine, as there was clearly in Aberdeen, to some degree in St Andrews, and even in Edinburgh under James Wedderburn (1585-1639) and John Cameron (1579-1626). If that made the difference, as to why the issue would be unavoidable from the side of the oppressor, what was it about Ogilvie, quite apart from his personality (outstanding courage, degree of conviction, and sense of obedience) that helps explain his being there at the wrong time? Bearing in mind that he seems to have spent three years in Paris (where he was ordained priest) and Rouen (1610-13), it would have been in the circles of the restored order in France where Ogilvie might well have encountered the new thinking on the mission and vocation of the Jesuit, not least in light of the Jesuit exegesis of Gospel passages.

\section{3} Jesuit Exegesis

In his great Isaiah commentary of 1616 , the Flemish Jesuit exegete Cornelius a Lapide (1567-1637) mentioned Ogilvie as one of his students who had achieved martyrdom - this must have been fresh in his mind, even as almost two decades later he came to write up his lectures on Isaiah. Although the finished commentaries on the Gospels came late in the second decade of the century

\footnotetext{
17 Nelson, Jesuits and the Monarchy, 160-63, 170: "In print and from the pulpit, Jesuits in France emphasized their own rejection of Jesuit scholars who published on tyrannicide."

18 Stefania Tutino, Law and Conscience: Catholicism in Early Modern England, 1570-1625 (London: Routledge, 2007), 104.

19 Tutino, Law and Conscience, 190.
} 
and he himself states that he had already published his ones on the Old Testament, he himself says that he started them in Leuven in 1600.

To consider his exegesis of the locus classicus of instruction to those finding themselves facing persecution (Matthew 10:11-23) Lapide is clear that Christ was referring prophetically to those going on mission after his death. Lapide has the style of one who does not want to bore his listeners, or inflict too much hard thinking on them, so he enjoys taking time to provide for his simple points (often borrowed from his predecessors) and gripping illustration from the lives of the saints.

And before governors, i.e., of provinces. So Paul was led as a captive before Felix and Festus, governors of Judea; James the Less before Ananias, the High Priest, by whom he was ordered to be slain; Peter and James the Great came before Agrippa, who struck off James' head. Peter and Paul were brought to Nero, under whom they at length underwent a glorious martyrdom. Thus, too, S. Andrew was led to Aegeus, the pro-consul of Achaia, by whom he was crucified; S. John to the Emperor Domitian, by whom he was placed in a cask of boiling oil, from which he gloriously came forth. From such things it will be seen that what Christ now says does not refer to this first sending the Apostles into Judea, for we do not read of any such things happening then, but of things which were to happen in their future life. ${ }^{20}$

But when they shall deliver you, \&c. This is the eleventh precept of Christ, by which he forbids the Apostles being anxious about their answers to the questions of the governors, because He promises that He will Himself

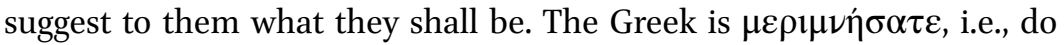
not be anxious and solicitous. He does not forbid their prudently premeditating an answer, but forbids an anxious and troubled care about it. By the martyr in his questionings and torments God must be assiduously invoked that He may inspire him with wisdom to answer, and courage to endure. This is what Luke says Christ promised, I will give you a mouth and wisdom which none of your adversaries shall be able to gainsay or resist. Thus it is said of S. Stephen. ${ }^{21}$

Lapide thinks of the martyr as answering any question wisely, even wittily while bearing up under pressure, and he embellishes the Lucan promise, with

20 Cornelius a Lapide, Commentary on the Four Gospels (London: John Hodges, 1887), 28.

21 Lapide, Commentary on the Four Gospels, 29. 
Stephen the protomartyr brought in to illustrate: "They were not able to resist the wisdom and spirit with which he spoke." He then offers a famous example of the literal fulfillment of this promise in the life of Saint Lucy of Syracuse (283-304) who, when she was ordered by the governor Paschasius to sacrifice to the gods, boldly refused. The story, which revolves around the preservation of chastity goes on, with a rather fabulous "air":

But when they shall persecute you, \&c.-Flee, "not," says Bede, "from fearing suffering, but by yielding, so that the occasion of tribulation may become the seed of the Gospel," lest by the slaying of the preachers the preaching of the faith should be cut off, but by their fleeing it may be scattered in other places. This flight was indeed victory. For they fled not through fear, but from love to Christ, that they might propagate His faith. So the Tartars, as they flee, cast their darts at their pursuing enemies, and so transfix and slay them. You will ask whether this be a precept, or only a permission. I reply, it is partly a precept, as when the necessity of the Church, or the faith, or peril of one's own fall, requires flight. For "he does not deny Christ by flying, who flies lest he should deny," says S. Chrysostom. So S. Nazianzus. (Orat. 1 in Julian) and Athanasius (de fuga sua), For had he not fled from the rage of the Arians, they would have triumphed over the Homoousian faith, which seemed to stand or fall with Athanasius. It is partly a counsel, as when greater benefit is expected for oneself or others from flight. It is partly a permission, as when any one has an excessive dread of torments; and he is not bound by any necessity or obligation (as being a bishop or pastor, for example) to remain in a particular place. For otherwise it is unlawful to flee if peril, or scandal, be likely to accrue. ${ }^{22}$

One need not impugn Lapide of moral cowardice for making use of the occasion to tell stories of holy romance, for it might strangely be the case of a realism that in the world of his time it might be better to flee, and in fact the presumption is that one should: it is both a counsel (an extra duty) and a permission to do so, with plenty of authority among the fathers. What if Athanasius (300-73) had not fled? Might the world not now be Arian? Only the very holy, the martyrs are to be trusted with martyrdom. The work wherein Tertullian (155-220) described flight as unlawful was composed while he was a heretic. Before being distracted about the meritorious nature of martyrdom 
compared with almsgiving, Lapide concludes with a flourish, one that romanticizes martyrdom, or at very least gives it an exotic and remote setting:

Martyrdom is the confession of Christ and the profession of Christianity, even to torments and a cruel death, and therefore it is the highest love and honouring of Christ. Wherefore the Apostles and Apostolic men have most ardently desired martyrdom. S. Ignatius in his Epistle to the Romans, says, "My love is crucified. There is not in me a fire of earthly, but of heavenly fuel. And I have living water which saith inwardly, Come to the Father." S. Basil says (Hom. 19 in S. Gordium, Mart.), "The martyrs speedily attain to heavenly glory by a violent and premature death. They endeavour speedily to migrate from this life, which ought rather to be called a lingering death, by means of short toil." We see, therefore, that he does not call death death, but as S. Sophia said to her daughter Anastasia (apud Surium, Octob. 25), "A good thing is departure from an evil world. It is joy, gladness, pleasure, splendour, beauty, light, a sweeter and fairer than earthly light." S. Anthony, as S. Athanasius testifies. ${ }^{23}$

Yet one wonders just how much influence the colorful, nostalgic and, frankly, irenical approach of Lapide, who effectively replaced the much more pugnacious Thomas Stapleton (1535-98) at Leuven, had on one like Ogilvie, once he was in France, as he was considering his mission to Scotland. To mention Stapleton: that Englishmen himself wrote a large amount, but his exegetical work is marked by two things: it follows the lectionary, it is directed to the Catholic faithful (including priests) rather than Jesuits, or those who were in any sense "apostolic" in their ministry, and also it is marked, and the exegesis almost overtaken, by often strident polemical and apologetic purposes. Therefore, Stapleton does not touch on Matthew 10 or Luke 12, where Jesus tells his disciples how to behave when arrested for the gospel. We have to make do with a brief discussion of Matthew 22:21 ("Render unto Caesar what is Caesar's"). This includes a disparaging remark on how wrong the "Anglocalvinists" (his dislike of the Puritan William Whitaker (1548-95) was matched only by his distaste for John Calvin (1509-64) and Theodore Beza (1519-1605) themselves, not least for their refusing to allow Jesus to be called "a legislator") were in maintaining that it is for the monarch to judge in matters of religions. ${ }^{24}$

\footnotetext{
23 Lapide, Commentary on the Four Gospels, 39.

24 Thomas Stapleton, Promptuaria moralia super evangelia dominicalia (Douay, 1589), 70: "Of quite a different character were the Promptuaria catholica super evangelia dominicalia, which appeared a year earlier. Stapleton hoped this book of commentaries would provide
} 
A much more compelling case can be made for the work of a third Jesuit, the Spaniard Juan Maldonado (1533-83), as being Ogilvie's kind of theologian. His excellent Commentary on the Gospels is a work of impressive erudition and insight: the best editions of it are those of Pont-a-Mousson (in folio, 1595). He worked on these during a retreat in Bourges after falling out with his benefactors at Lorraine, and before his triumphant summons to Rome. He probably finished these commentaries in 1583 . An epitome of these works (Summula) was made in 1604 by Martin Condognat at Lyon, which goes to show just how popular his work remained, and with wide circulation particularly in France in that first decade of the 1600 . And with good reason: the historian of exegesis Henning Graf Reventlow saw the Golden Age of Jesuit biblical scholarship as ushering in a new stage in which the two fields (Scholastic and biblical) are led back together again. ${ }^{25}$

On Matthew 10:17-23, the passage where Jesus gives advice to those who will go forth as apostles to preach and who will be arrested and examined, Maldonado starts slowly. At first his interest seems purely "historical," as in his discussing the term "in conciliis" of verse 17 as meaning either synagogues or tribunals. Yet suddenly the comments turn at once more theological and more applicable to the post-Reformation age, as on Matthew 10:19:

Christ tells us not to be too afraid and worried, as in the Greek word: $\mu \varepsilon \rho \mu \nu \eta \eta \sigma \alpha \tau \varepsilon$. In the same way Mark here is to be understood, and in what Luke (12:12): put it in your ears not to premeditate how you will reply [to the interrogator]. He does not forbid every prepared thought, but

a useful manual for popular preachers who had to deal with congregations exposed to heresy. It covered the same ground as the Promptuaria moralia, but the commentaries were much shorter (two or three pages at most) and much more pointed." See Thomas Stapleton, Opera omnia (Paris, 1620), 665 (Promptuarium Catholicum: Dominica XIII post Pentecotem): "At hodie haeretici praedicti Caesari, id est, Regibus \& Magistratibus non solum ea quae eorum sunt, sed etiam ea quae Dei sunt reddere volunt. Sustinent enim Regum esse iudicare de fide, cognoscere de doctrina, discernere veros prophetas a falsis, instituere pastores \& ministros verbi, de toto cultu \& politia Ecclesiastica leges ferre."

25 Henning Graf Reventlow, History of Biblical Interpretation, 4 vols. (Atlanta: SBL Press, 2009), 3:204, cf. Jared Wicks, "Catholic Old Testament Interpretation in the Reformation and Early Confessional Eras," in Hebrew Bible/Old Testament: The History of Its Interpretation, Vol. 2: From the Renaissance to the Enlightenment, ed. Magne Sæbø (Göttingen: Vandenhoeck \& Ruprecht, 2008), 617-48; Wim Francois, "Augustine and the Golden Age of Biblical Scholarship in Louvain (1550-1650)," in Shaping the Bible in the Reformation: Books, Scholars and Their Readers in the Sixteenth Century, ed. Bruce Gordon and Matt McLean (Leiden: Brill, 2012), 235-89. 
rather that which would mistrust divine providence and its present help and get in the way of fearless and worry-free preaching of the gospel. ${ }^{26}$

\section{Then on verse 20:}

Not so much you as the spirit of your Father, i.e. in the sense and counsel you will reply as in "I desire mercy not sacrifice," not so much sacrifice as mercy, without excluding 'you'. See what we have written on that verse. The power of the statement is not your affair, but is mine and your Father in heaven's business, that the Spirit that is the advocate of my Father will reply even as you are silent, just as the author of the unfinished commentary on Matthew and Jerome seem to interpret. ${ }^{27}$

Here is a case of Maldonado finding an Aristotelian-Thomistic measuredness: the assurance of a gift of divine speech does not mean total human inaction. Yet the contribution of the witness is that of silence, even the silence that accompanies mental reservation. With you being silent the Advocate in heaven will respond. The Holy Spirit will speak to the minds of the interrogators and any audience, by-passing the lips of the witness.

At the end of the section on v.23 ("Flee from one city to the next"), he concludes:

When they persecute you. He has previously said: be prudent. This teaches one part of prudence, that they flee the snares of the enemies and be

26 I have used a nineteenth-century edition: Joannis Maldonati Societatis Jesu theologi: Commentarii in quatuor evangelistas quos pristinae integritati restitutos, novisque studios auctos denuo edidit J. M. Raich (Mainz: Francisci Kirchheim, 1874), 218-20: "noli cogitare. Non docet esse negligentes atque vecordes, sed nimis timidos et sollicitos ese pro-

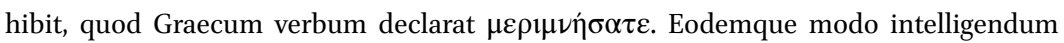
quod Marcus dicit [...] et quod Lucas Ponite ergo in cordibus vestris, non praemeditari, quemadmodum respondeatis. Non enim omnem praecedentem meditationem vetat, sed eam, quae diffidentiam divinae providentiae et opis habeat quaeque nimio metu ac sollicitudine liberam Evangelii praedicationem impediat."

27 Commentarii in quatuor evangelistas quos pristinae integritati restitutos, 20: "Non enim vos estis. Non tam vos, quam spiritus Patris vestri, sed illius sensu consilioque respondebitis, ut supra: misericordiam volo, non sacrificium, id est, non tam sacrificium, quam misericordiam. Vide, quae ad illum adscripsimus locum. Vis haec est sententiae, non est vestra causa, sed mea et Patris vestri, qui in coelis est, quare Paracletus, id est meus Patrisque advocatus etiam vobis tacentibus respondebit, ut videntur Auctor imperfecti et Hieronymus interpretari." 
careful around people, as v.17 warned. For Christ does not want his soldiers to fight, but to flee. Two matters here are disputed by interpreters; whether in the first mission of the Apostles these things are said; the other, how he orders to flee, when after all it says in John's Gospel, that the good shepherd lay down his life for his sheep, while the mercenary when he sees the wolf coming flees. Indeed, that this refers only to the first mission is affirmed by many important authorities (Tertullian; Jerome; Chrysostom). ${ }^{28}$

Quietly the point is made: flight is not an option for a pastor. To reinforce this, he continues on verse $23,{ }^{29}$ that here Christ is not necessarily talking about

28 Commentarii in quatuor evangelistas quos pristinae integritati restitutos, 23: "Cum autem persequuntur vos. Dixerat v.16 Estote prudentes, docet nunc partem unam prudentiae, qua adversariorum fugiant insidias, et ab hominibus caveant, ut v.17 monuerat. Non vult Christus milites suos pugnare, sed fugere. Duo hic ab interpretibus disputantur: alterum, an haec in hac prima Apostolorum missione dicta sint; alterum, quomodo fugere jubeat, cum apud Joannem doceat, bonum pastorem animam suam ponere pro ovibus suis, mercenarium autem, cum videt lupum venientem, fugere. Haec ad solam primam missionem pertinere multi et graves volunt auctores (Tertullianus Hieronymys; Chrysostomus, hom 35). Alii generaliter ad omnem missionem totumque Apostolorum officium extendunt, ut illa, quae v.9 dicta sunt, ut sentire videtur Origenes et Athanasius et Gregorius Nazianzenus. Quod multo mihi videtur esse probabilius."

29 Commentarii in quatuor evangelistas quos pristinae integritati restitutos, 219-20: "Nam in prima quidem missione nihil ejusmodi Apostoli sunt experti, quamobrem ab una civitate in aliam fugere deberent, omnia illis ex voto successerunt, itaque laeti gloriantesque redierunt, quod ipsa sibi daemonia subjicerentur. Quod Christus antequam fieret, ignorare non poterat. Sententia igitur est generalis, sed occasione, non necessitate primae missionis a Christo pronuntiata. Caeterum priores illi auctores, quos nominavimus, non ad exitum rei, ex quo potissimum Christi praedictio erat intelligenda, sed ad illa sola verba, quae sequuntur, animum attenderunt, non consummabis civitates Israel, donec veniat Filius hominis. Altera quaestio, quomodo fugere Apostolos Christus doceat, neque subtilius, neque copiosus, neque elegantius, quam ab Augustino tractata est, disputari potest. Illud tamen non definivit, an quod Christus hoc loco tradit, praeceptum sit, an consilium. Athanasius quiden et Gregorius Nazianzenus praeceptum vocant, sed vulgariter fortasse loquuntur. Ego utrumque pro diversis loci, temporis, personarum et rerum circumstantiis esse arbitror, sed proprie a Christo propter primam potissimum missionem et magnam partem secundae tanquam praeceptum traditum. Voluit enim Apostolis praecipere, ut sese propagando latius Evangelio reservarent, nec se in primo statim proelio objicerent morti; nondum tempus illis esse moriendi, diu prius pugnandum esse, longe lateque fines regni Dei proferendos. Miles, qui fugit (ut Graeco dicitur proverbio, iterum pugnabit. Hoc sensu praeceptum est. Hoc sensu Christus ipse saepe fugit, primum in Aegyptum infans, deinde cum eum Nazarethani ipsius cives praecipitare voluerunt, nondum enim venerat 
the mission of his disciples. Maldonado recommends Augustine's interpretation here but does not rehearse it. Is "flee" a counsel or a precept? Athanasius (296-373) and Gregory Nazianzen (329-90) called it a precept but they were possibly speaking rather loosely. Christ here wanted his apostles to survive the first mission, for it was not yet their time to die. It is a precept in the same sense as "live to fight another day," and this is one Christ himself observed when he slipped away from the crowds at Nazareth, for his time had not yet come. Then Maldonado states the general precept that applies in every way to Christians (soldiers of Christ). To flee is not fear but piety; not to flee is not courage but obstinacy. The greater glory of God and the usefulness to the church ought to be our rule. The gospel itself demands that we flee, so we must. But then Maldonado narrows down the application of the verse to priests. A priest is allowed to flee when he is examined privately by his enemies, and when there are others who could administer the sacraments on his behalf, and when all this flock is scattered. Thirdly when it would help more to flee than to stay. By fleeing one does not deny Christ. Otherwise it is not allowed, however: one must stay and give life for the sheep. So, it seems that the presumption is that a priest will stay.

That is the way vows work after all. It exempts a priest (and in missionary settings a Jesuit priest) from obeying the precept to flee. This is the kind of mind that Ogilvie, a man well and truly educated in Jesuit contexts (at Brno, Jindrichuv Hradec, and Olomouc) seems to have had. ${ }^{30}$ He had a formation

hora ejus. Simili in causa non iis etiam, qui postea future erant. Nobisque omnino omnibus praeceptum est. Nam cum Evangelium ipsum, propter quod fugiendum non est, postulat ut fugiamus, fugiendum est. Tunc fugere non metus, sed pietas; non fugere, non fortitudo, sed pertinacia est. Hac de causa D. Paulum fugisse legimus. Major Gloria Dei et Ecclesiae utilitas regula nobis esse debet; cum aut utraque, aut alteruta, ut fugiamus a nobis exigit, non fugere peccatum est, Aliis casibus non debemus, an autem possimus, alia est quaestio, quam solam Aug explicavit. Primum fugere sacerdoti licere, quando ipse privatim ab adversariis quaeritur, et sunt allii qui possint pro illo sacramenta populo minsitrare. Quando omnes ejus oves fuga dissipatae sunt. Tertio, quandocumque plus fugiendo, quam manendo juvare potest. Addit Chrysostomus fugere licere, et nescio an oportere, cum ejus, si manserit, fides periclitabitur (will prove): Christum, inquit, fugiendo non negat, qui ideo fugit, ne neget. Alias non licet, alias manendum est, et pro ovibus animam ponenda, quod mercenarius non facit, qui quandocumque videt lupum venientem, et reliquit oves et fugit. Tertulliani vero sententia, qui nunquam fugere licere ulli Christiano existimavit, merito damnata est; illiusque de fuga in persecutione librum adversus Ecclesiam scriptum esse Hieronymus in ejus vita dicere non dubitat."

Thomas McCoog, S.J., "Pray to the Lord of the Harvest': Jesuit Missions to Scotland in the Sixteenth Century," Innes Review 53, no. 2 (2002): 127-88. According to Johannes Schmidl, S.J., Historiae Societatis Jesu Provinciae Bohemiae, 4 vols. (Prague, 1747-64), I, 463: "as 
that was second to none in its variety and "roundedness." ${ }^{31}$ Saying Mass was a crime in terms of the civil law going back to 1560 , but of course a number of exemptions and indulgences had since been granted. It would normally have been dealt with through deportation, and that had been the usual practice a decade or two earlier, ${ }^{32}$ but more now was at stake: allegiance to spiritual theology. And driving the determination not to back down was the realization that the matter was public, there was a flock to be ministered to. Martyrdom would be the ultimate sacrament, an idea reinforcing the practice of martyrdom that goes back to Ignatius of Antioch (35-108).

The Scottish church as it found itself in its Reformed state in the 1590s would find imposed upon it, in a theoretical caste equivalent to the practical, even pragmatic, steps taken by Elizabeth I(r.1558-1603) in England, a high doctrine of divine right kingship, at least in germ. The allegiance demanded to the king, although likely more to do with an alliance of royal drive to hegemony allied with Protestant fervor, ${ }^{33}$ soon took on religious overtones and were bound to come into collision with the Jesuit doctrine of papal power, which served to

Prague had been blessed in the Englishman Campion, so Olomouc in the Scot Ogilvie. Both colleges prepared their respective charges for the glory of suffering." McCoog's conclusion is that after 1603 the Scots mission focused on sending fewer but better-trained Jesuits.

31 He entered the Scots College in Louvain in 1595 and was sent to the Scots monastery in Regensburg on June 27, 1598 (Records of the Scots colleges at Douai, Rome, Madrid, Valladolid and Ratisbon, Volume 1, ed. William Forbes-Leith [Aberdeen: New Spalding Club, 1906], 7). By the end of 1598, he was at Jesuit college in Olomouc (Scmidl, Historiae, 2:201; Brown, John Ogilvie, 16). 1600 novice, 1601 novice, Brno (ARSI, Austr. 123, fols. 43" $55^{\mathrm{r}}$ ); 1602 professor, 1603 professor, 1604 philosopher, 1605 philosopher, 1606 philosopher, Graz (ARSI, Austr. 123, fols. 61 $1^{\mathrm{r}}, 67^{\mathrm{v}}, 74^{\mathrm{r}}, 82^{\mathrm{v}}, 106^{\mathrm{r}}$ ); 1607 taught rhetoric, Jindfichuv Hrade (= Nova Domus) (ARSI, Austr. 123, fol. 117 ${ }^{\mathrm{r}}$ ); 1608 taught grammar, Vienna (ARSI, Austr. 123, fol. $119^{\mathrm{r}}$ ); 1609 theologian, 1610 theologian, Olomouc (ARSI, Austr. 123, fols. 160 ${ }^{\mathrm{r}}, 128^{\mathrm{r}}$ ); 1611 sent to Paris (ARSI, Austr. 123, fol. 173 ${ }^{\mathrm{r}}$ ); 1611, Paris (ARSI, Franc. 22, fol. $71^{\mathrm{r}}$ ); 1612 confessor, 1613 confessor, Rouen (ARSI, Franc. 22, fols. $82^{\mathrm{r}}, 94^{\mathrm{r}}$ ); 1613 sent to Scotland (ARSI, Franc. 11, fol. $5^{\mathrm{r}}$ ). See McCoog, "Pray to the Lord of the Harvest," 181-82.

32 McCoog, "Pray to the Lord of the Harvest," 149.

33 Paul Goatman, "Religious Tolerance and Intolerance in Jacobean Scotland: The Case of Archibald Hegate Revisited," Innes Review 67, no. 2 (2016): 159-181 shows how the eponymous "church papist" and his sons after the father's flight to Rome in 1612 were able to survive excommunications and reconciliation with the kirk, and adds: "Anderson's notes 
check royal pretensions. The Jesuit practice of allowing Catholics also to attend Protestant services - to be "crypto-" in a fuller sense-is arguably symptomatic of a worse scenario for the old faith compared with south of the border. ${ }^{34}$ Added to this was a spirituality, built around the core of teaching in the gospels where, even although lay Catholics are allowed leniency, ${ }^{35}$ Christ exhorts his front-line followers to martyrdom: the full richness of this "authentic" Christianity was the legacy of the Golden Age of Catholic exegesis, represented more by Maldonado, who applies the dominical teaching particularly to confessing priests. The changed direction of the ideological wind to a prevalent sort of Caesaropapism that the Jacobean polity reached in the second decade (after many years of distinguishing religion and politics) ${ }^{36}$ was complemented by a switch from activity to courageous passivity in the Jesuit understanding of priestly witness. These were the conditions of "perfect storm" in which John Ogilvie met his end.

on Scotland were found in Ogilvie's belongings when he was captured in Glasgow during the winter of 1614."

34 See Thomas M. McCoog, "And touching our Society": Fashioning Jesuit Identity in Elizabethan England (Toronto: Toronto University Press, 2013), 397.

35 See Alan Macinnes, "Catholic Recusancy and the Penal Laws," Records of the Scottish Church History Society 23 (1989): 27-63, and the summary in Goatman, "Archibald Hegate," 180 of an unpublished paper by Scott Spurlock, "Scottish Catholicism in the age of John Ogilvie."

${ }_{3} 6$ It is not the case that the prosecutor William Hay (bio dates) was quite accurate in emphasizing the political charge, since the indictment also mentions Ogilvie's saying of the Mass. His Relatio and Continuatio (Ogilvie's own account, at NLS, BCL S 165 is interpreted by Daniel McLeod, "Declining his Majesty's Authority': Treason Revisited in the Case of John Ogilvie," in Scotland's Long Reformation: New Perspectives on Scottish Religion, c.150o-c.166o, ed. John McCallum [Brill: Leiden, 2016], 179-201). 